\title{
A NEW ANT-LIKE CERAMBYCID BEETLE FROM HONDURAS
}

\author{
By W. S. Fisher \\ Of the Bureau of Entomology, United States Department \\ of Agriculture
}

In nearly all of the later works on Cerambycidæ the genus Eplophorus Chevrolat is placed as a synonym of Apelocera Chevrolat, but the former name seems to be valid and should be used for the species of this genus. Thomson (Classif. Ceramb., 1860, p. 229), under the genus Tillomorpha, gives lineoligera Blanchard as the typical species, and states that Tillomorpha spinicornis Chevrolat from Mexico and another species in his collection from Venezuela have the third joint of the antennae strongly spinose at the extremity, and should constitute a new genus, but he does not give it a new name. Chevrolat (Journ. Ent., vol. 1, 1861, p. 248) quotes Thomson's remarks on spinicornis, and states that he has proposed the name Eplophorus in a printed catalogue for this Mexican species. Chevrolat (Ann. Soc. Ent. France, ser. 4, vol. 2, 1862, p. 61) erects the genus Apelocera for a new species, waltli, from Brazil, also includes spinicornis, and in a footnote he says: "I propose to give Apelocera to the insects which I previously placed in the genus Eplophorus (Journ. Ent., vol. 1, 1861, p. 248), as I abandon Eplophorus since the root of this genus has not proper significance." In this same publication (Ann. Soc. Ent. France, ser. 4, vol. 2, 1862, p. 535), Chevrolat writes Apilocera instead of Apelocera, and this name has been used by Pascoe (Trans. Ent. Soc. London, ser. 3, vol. 5, 1866, p. 295), and also by Bates (Biol. Centr.Amer., Coleopt., vol. 5, 1880, p. $60 ; 1885$, p. 305). 
Eplophorus velutinus new species

Male.-Moderately large, elongate, black, and subopaque; elytra ornamented with a short, oblique, smooth, ivory fascia, extending from near the lateral margin to middle of each elytron.

Head about as wide as long, and nearly flat in front, sides nearly parallel between the eyes, flat between the antennal tubercles, which are very widely separated and scarcely elevated, surface coarsely, irregularly punctate, more or less longitudinally rugose, sparsely clothed with short, recumbent, white hairs, with a very long seta arising from a large puncture on each side behind the epistoma; eyes small, finely granulated, distinctly divided, lower lobes rounded, upper lobes very small and narrow. Antenna eleven-jointed, about three-fourths as long as the body, sparsely clothed with very short cinereous pubescence and a few long, moderately stiff, black hairs; first joint robust, about three times as long as wide; third joint nearly as long as the following three joints united, and armed with a very long spine at apex; fifth joint slightly longer than fourth and both joints armed with a short spine at apex.

Pronotum slightly longer than wide, slightly narrower at base than at apex, and strongly convex; sides strongly arcuately rounded, and more strongly constricted at base than at apex; surface sparsely covered with elongate elevations, rather densely clothed with recumbent, yellowish pubescence, with numerous long, erect hairs intermixed, the pubescence shorter and more inconspicuous on apical half, with a small, round, conspicuous, black, pubescent spot on each side in front of the middle. Scutellum narrowly triangular, and densely clothed with recumbent, yellowish pubescence.

Elytra about twice as long as wide, and at base about equal in width to the pronotum at middle, strongly, abruptly deflexed at base, arcuately deflexed at apex, strongly, transversely depressed at middle, humeri distinct, and strongly elevated, a large longitudinal callosity on each side near the base, at middle a moderately wide, oblique, glabrous fascia, 
in front of which is a narrow, oblique, smooth, eburneous fascia, extending from near lateral margin to middle of each elytron; sides nearly parallel to behind middle, where they are strongly, arcuately expanded, with the tips broadly truncate; surface finely, densely punctate, except on middle glabrous fascia and tops of the callosities, where it is coarsely, confluently punctured, rather sparsely clothed on basal half with long, recumbent, yellowish pubescence, apical half densely clothed with long, silky, golden yellow pubescence, which conceals the surface, and with numerous long, erect hairs intermixed over the entire surface.

Beneath finely punctate, with a few coarse punctures intermixed, sparsely clothed with recumbent pubescence and a few long, erect hairs intermixed, pubescence golden yellow on abdomen and silvery white on rest of surface. Legs long, sparsely clothed with short, white pubescence, and long, stiff, black and white hairs intermixed; femora strongly expanded at middle; tibiae slightly arcuate, strongly flattened, and longitudinally carinate.

Length, 9-10 mm.; width, $2.8 \mathrm{~mm}$.

Type locality.-Prieta, Republic of Honduras.

Other localities.-San Pedro, Honduras. Cacao, Trece Aguas, Alta Vera Paz, Guatemala.

Type, allotype, and paratypes.-Cat. No. 43479, United States National Museum.

Described from four examples, two males (one type), and two females. The type (male) and one male paratype collected at the type locality, April 5, 1924, by Dr. J. Bequaert, allotype collected at San Pedro, Honduras, April 21,1923 , by S. C. Bruner, and one paratype collected at Cacao, Trece Aguas, Alta Vera Paz, Guatemala, by G. P. Goll.

This species is very closely allied to magna Bates, but differs from that species in being smaller, the pronotum not much longer than wide, with the entire apical half of the elytra densely clothed with silky, golden yellow pubescence. In the two females the pronotum and basal half of the elytra are not clothed with yellowish pubescence. 

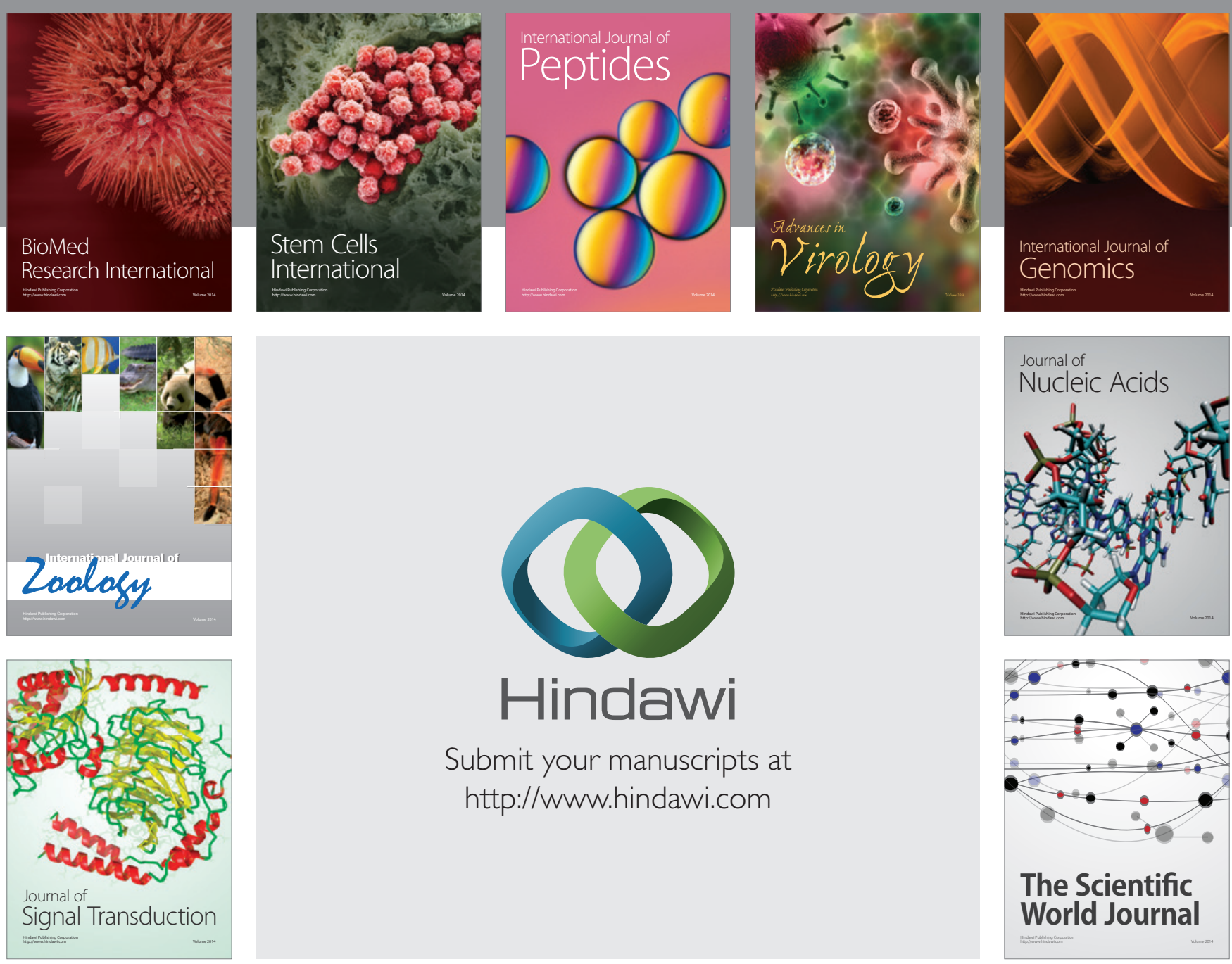

Submit your manuscripts at

http://www.hindawi.com
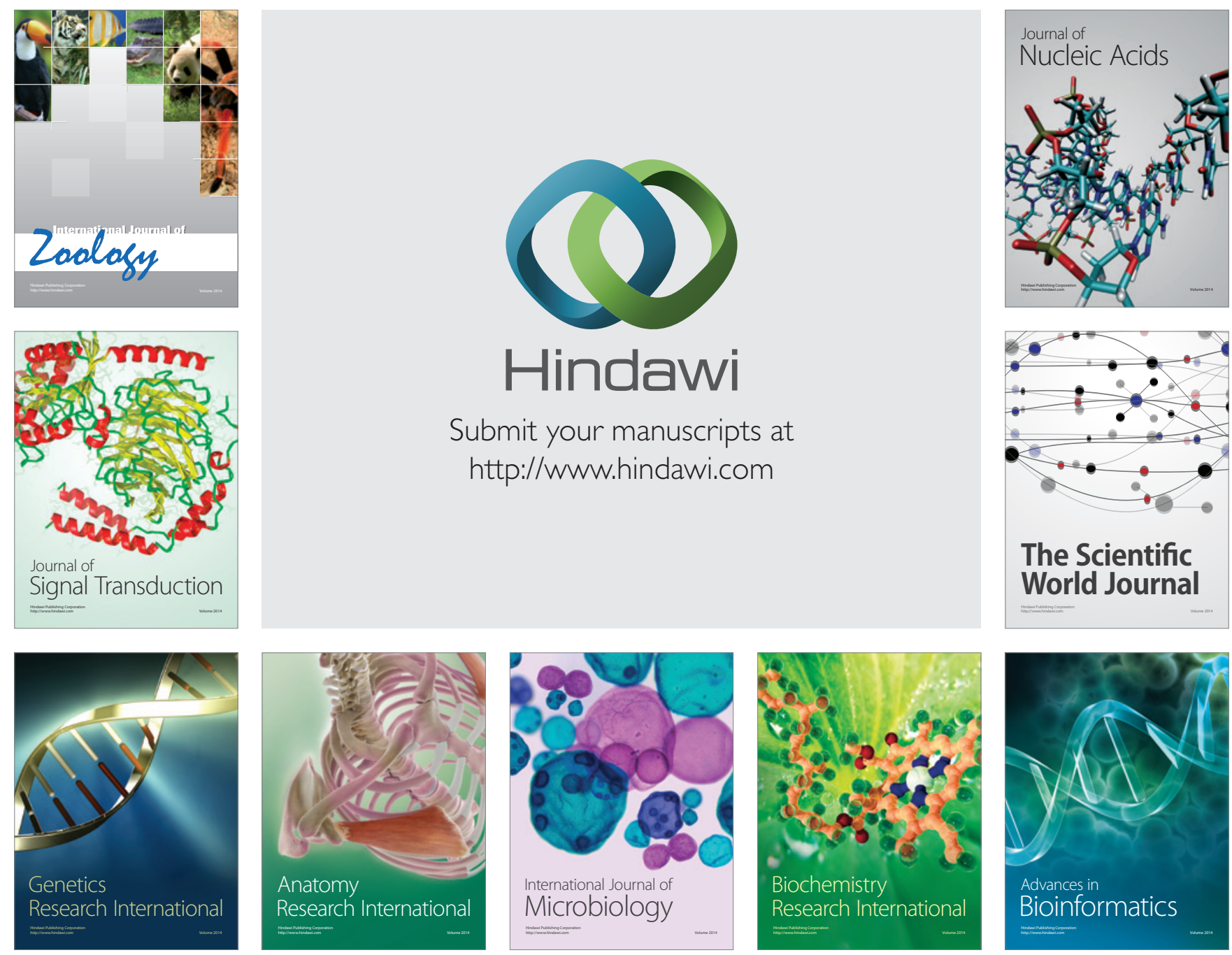

The Scientific World Journal
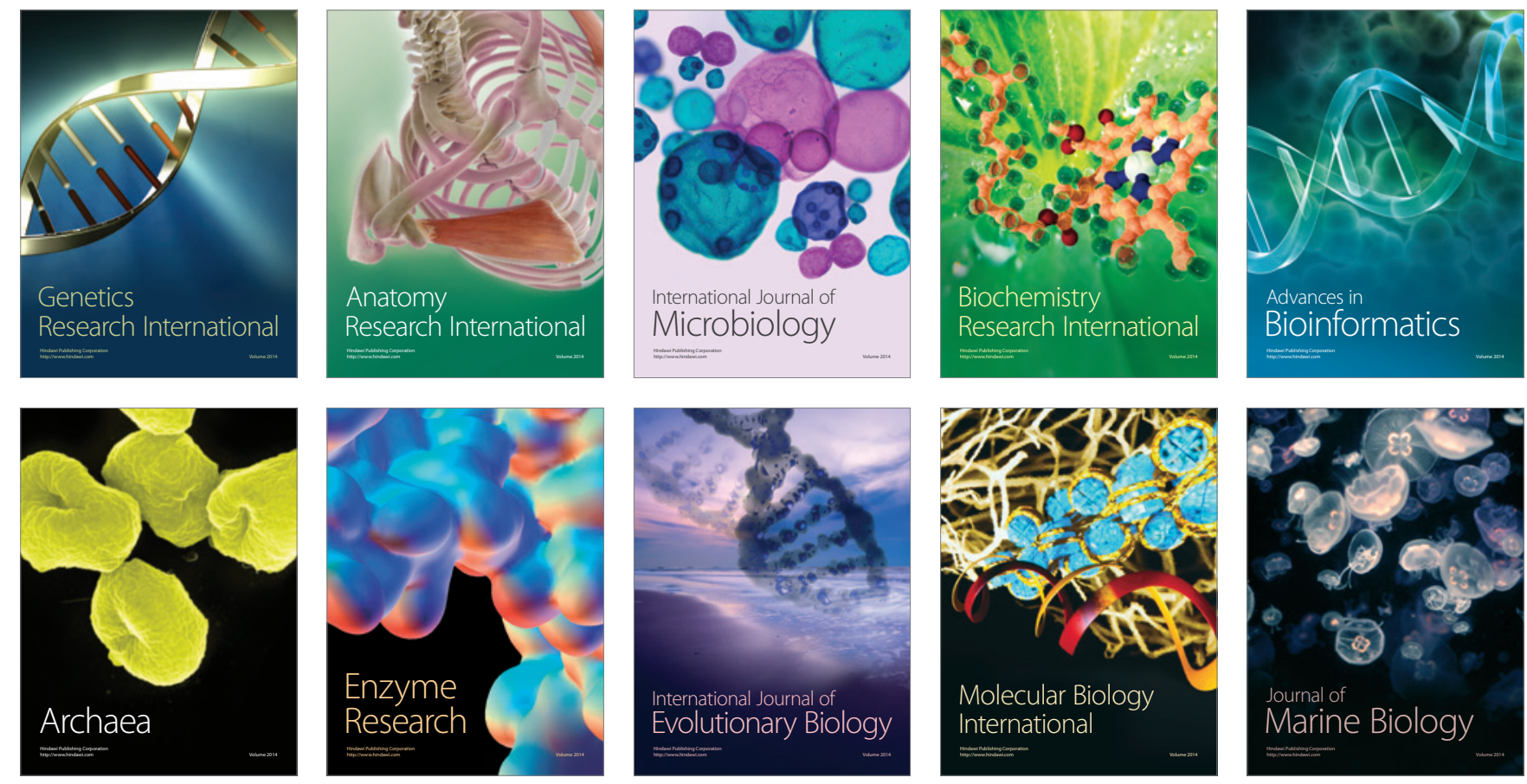